\title{
Az információs technológiák segítő alkalmazásai
}

A tanulmány szerzői áttekintést nyújtanak a fogyatékkal élők és az idősek számára készített informatikai eszközök fejlesztésének irányairól. Először körüljárják a fogalom különböző meghatározásait és a megváltozott képességek rendszerezési lehetőségeit. Bemutatják a funkcióképességnek, a fogyatékosságnak és az egészségnek a WHO által elfogadott nemzetközi osztályozási rendszerét (ICF) és annak alkalmazását a területen. A tanulmány második részében példákat mutatnak be a segítő technológiák alkalmazásaira, különös tekintettel a hazai fejlesztésekre, illetve a csúcstechnológiát képviselő nemzetközi megoldásokra. A segítő rendszerek egy része körülveszi a fogyatékkal élő vagy idős felhasználót, egyfajta intelligens környezetet biztosítva számára, míg más eszközök egy-egy funkció gyakorlásában vagy valamilyen tevékenység végzésében vannak használóik segítségére. Az utolsó részben áttekintést kapunk azokról a kritikus sikertényezőkről, melyek kulcsszerepet töltenek be abban, hogy mely termékeket használnak csak szűk körben, és melyeket alkalmaznak és fogadnak el a speciális igényủ célcsoportokban.

Kulcsszavak: segítő technológiák, osztályozás, ICF, környezeti intelligencia, agy-számítógép interfész, bionikus technológia, kritikus sikertényezők

\section{Szerzői információ:}

\section{Laufer László}

pszichológus, a BME Ergonómia és Pszichológia Tanszékének tanársegédje. Jelenleg az ELTE pszichológiai doktori iskolájának hallgatója, disszertációját készíti. Rendszeresen közöl a mesterséges intelligenciával és a jövố technológiáival kapcsolatos tudományos ismeretterjesztố írásokat több hazai internetes és nyomtatott újságban. Az Agent Portal nevú tematikus oldal főszerkesztốje. Kutatási területei: ember-számítógép interakció, érzelmi számítás(tudomány), intelligens interfészek, beszélgető ágensek, továbbá a segítő technológiák.

\section{Koncz Péter}

a BME végzốs múszaki menedzser szakos hallgatója, jelenleg diplomamunkáját készíti az interaktív érintốképernyốs eszközök fejlesztési lehetôségeiról. Érdeklôdési területei közé tartozik az ember-számítógép interakció, ezen belül használhatósági vizsgálatokkal és elemzésekkel foglalkozik.

\section{Így hivatkozzon erre a cikkre:}

Laufer László, Koncz Péter. „Az információs technológiák segítő alkalmazásai”.

Információs Társadalom VIII, 2. szám (2008): 77-88.

https://dx.doi.org/10.22503/inftars.VIII.2008.2.5

A folyóiratban közölt müvek

a Creative Commons Nevezd meg! - Ne add el! - Így add tovább! 4.0

Nemzetközi Licenc feltételeinek megfelelően használhatók. 
Laufer László - Koncz Péter

\section{Információs technológiák segítố alkalmazásai}

\section{Bevezetés}

A nemzetközi és a hazai informatikai kutatásoknak is egyre népszerúbb területe az úgynevezett „segítő technológia” (Assistive Technology), magyar betúszóval ST. Általános értelemben az ST-hez sorolják a rehablitációs segédeszközöket, használati és lakberendezési tárgyakat is, de az utóbbi idóben jobban elterjedt a kifejezés szúkebb értelemben vett alkalmazása, amikor kizárólag az ilyen célokra felhasznált információs és kommunikációs technológiákat értik rajta.

Az ST fókuszát nehéz pontosan körülhatárolni, hiszen az összes informatikai alkalmazás célja az emberi feladatvégzés megkönnyítése, a környezet megismerése, a problémamegoldás, a társakkal való kommunikáció korlátainak kiterjesztése és a lehetốségek bơvítése a hatékonyabb munkavégzés és a kényelmesebb életvitel reményében. Ahogy a fogyatékkal élók és az átlagosnak tekinthetô emberek közt sincs éles határvonal, azt is nehéz meghatározni, hogy egy információs technológiai alkalmazás milyen ismérvek alapján tekinthetô ST-nek. Miben térnek el a fogyatékkal élók, az idôsek, a gyerekek, a digitális szakadék túloldalán elhelyezkedő társadalmi csoportok részére fejlesztett eszközök a hagyományos rendszerektól?

Amint az ST-alkalmazások osztályozásánál látni fogjuk, a válasz nem annyira a fent említett társadalmi csoportok defektusainak sorra vételéból, mint inkább a speciális felhasználói csoportok lehetốségeinek, igényeinek és az átlagostól eltérố használati szituációinak megismeréséból adódik.

Jelen cikkünkben megpróbálunk áttekintést adni a segítô technológiák osztályozásának lehetôségeiról, példákat hozva az figyelem fókuszában álló részterületeken történő fejlesztési irányzatok és konkrét alkalmazások köréból, különös tekintettel a magyarországi kutatómúhelyek tevékenységére. Írásunkban fóként az idôsek és a fogyatékkal élók számára létrehozott rendszerek bemutatására koncentrálunk. A digitális szakadék áthidalására, a nehéz szociális helyzetben élók és a funkcionális analfabéták segítése érdekében történố fejlesztésekról helyszúke miatt nem áll módunkban beszámolni. Bár tematikailag ezek a területek is az ST-hez sorolhatók, szerteágazó vizsgálatuk szétfeszítené egy rövid tanulmány kereteit.

\section{A segítő technológiák meghatározása}

A segítố technológia szakkifejezésnek számos értelmezése létezik. Az egyik általánosan elfogadott meghatározás minden olyan eszközt vagy rendszert magába foglal, amely lehetôvé teszi az egyes személyek olyan feladatainak elvégzését, amelyeket egyébként nem lennének képesek végrehajtani, vagy megkönnyít és biztonságosabbá tesz bizonyos cselekvéseket (Cowan-Turner-Smith 1998). Az Egészségügyi Világszer- 
vezet (WHO 2004) is ezt a definíciót alkalmazza. A segítő technológiákkal foglalkozó brit alapítvány (King’s Fund 2001) így definiálta a fogalmat: „Segítố technológia minden olyan termék vagy szolgáltatás, amit a speciális helyzetú és idốs emberek függetlenségének növelésére terveztek." Fontos megemlíteni továbbá Hoppestad meghatározását (Hoppestad 2006): „A segítő technológia támogatja és segíti a felhasználót akár speciális, akár átlagos feladatainak ellátásában, egy meghatározott környezetben.” Ez utóbbi megfogalmazás a legegyszerúbb, de egyúttal a leginkább univerzális is, hiszen nem különíti el a fogyatékkal élóket az átlagemberektól. A definíció utal arra, hogy legtöbb embertársunknak van valamilyen problémája, amely gátolja cselekedeteinek végrehajtásában. Gondoljunk a szemüvegesekre, akik segédeszközük nélkül nagyban korlátozottak lennének, vagy akik erdei sétákon botra támaszkodva mennek a nehezebb emelkedókön. A számukra készített segédeszközök csak összetettségükben és használatuk gyakoriságában térnek el a fogyatékkal élók által használt tárgyaktól.

\section{A segítő technológiák fejlődése}

A segítố célú alkalmazások organikusan alakultak ki az informatikai rendszerek fejlődése során. Egyrészt, mint említettük, az ember-számítógép rendszerek célja a kezdetektól fogva a felhasználó segítése volt. Másrészt az informatikai alkalmazásokra általánosan jellemzó, hogy fejlesztóik gyakran megelózik koruk felhasználói igényeit, és olyan rendszereket hoznak létre, melyek iránt az adott időpontban nem jelentkezik különösebb kereslet. Az így születố alkalmazások gyakran évekig csak a laboratóriumok és a tudományos világ számára hozzáférhetók.

Az ilyen rendszerek - bravúros tudományos újításaik ellenére - sokszor nem jutnak el a felhasználókhoz, mivel az üzleti modellen kívül az emberi tényezó, a rendszer használhatósága sincs eléggé kidolgozva. Az ember-számítógép interakció (Human Computer Interaction, HCI) kutatói azt szokták mondani, hogy minél nagyobb a társadalmi, kulturális, gondolkodásbeli távolság egy szoftver készítói és felhasználói között, annál nehezebben értik majd a felhasználók a rendszert, és annál kevésbé tudják megfelelốen alkalmazni annak funkcióit. A használhatósági (usability) szakértối ezt a szakadékot hivatottak áthidalni, bizonyos közvetítő szerepet betöltve, a két sokszor ellenérdekelt fél között.

Ez a távolság gyakran rendkívül jelentốs az ST esetében, ahol a laikusok számára intuitíve tulajdonképpen lehetetlen pontosan felmérni a felhasználók igényeit. Az ilyen rendszerek általában úgy jönnek létre, hogy egy meglevố ötlethez keresnek alkalmazási lehetôséget, amit egy fogyatékkal élő felhasználói helyzetben vélnek felfedezni.

Napjainkban az Egyesült Államokban, Kanadában és az Európai Unióban az ST lényeges változáson megy keresztül annak köszönhetően, hogy az életszínvonal és a társadalmi felelôsségvállalás növekedésével jelentốs társadalmi igény mutatkozik a fogyatékkal élók életminőségének javítására. Következésképpen ezeken a területeken számottevố a piaci kereslet az ilyen technológiai alkalmazásokra, különös tekintettel az idősek számára fejlesztett eszközökre, mivel ez a társadalmi csoport sok helyen jelentôs vásárlóerốt képvisel. Ezekben az országokban sorra alakulnak az ST-vel foglalkozó laboratóriumok, ahol a használhatósági szakemberek kapják a vezetố szerepet, ók határozzák meg a fejlesztési irányokat. 


\section{A segítő technológiák osztályozása}

Mint korábban említettük, kezdetben a terület inkább csak párhuzamosan, mintsem szoros együttmúködésben fejlốdött a fogyatékkal élók és az idôsek problémáival foglalkozó társadalomtudományokkal és az orvostudománnyal. A gyógypedagógus, pszichológus, ergoterapeuta szakemberek és az orvosok is a tudományuknak megfeleló osztályozási módszereket használtak, így nem csoda, hogy a folyamatba legutolsóként bekapcsolódó informatikusok is az általuk fejlesztett eszközök tulajdonságai szerint közelítették meg a kérdéseket. Az IKT-rendszerekben ezért gyakran találkozunk túlságosan általános leírásokkal (például „vakok és gyengénlátók”, „mozgássérültek” stb.). Értelemszerúen szükség van tehát valamilyen egységes klasszifikációs rendszerre, melynek segítségével mind a fogyatékkal élók, mind az alkalmazott terápiás módszerek és rehabilitációs eljárások, köztük az ST-megoldások is leírhatóvá válnak.

\section{Az ICF szerinti klasszifikáció}

Az Egészségügyi Világszervezet (World Health Organization, WHO) a 80-as években kezdte el fejleszteni, és 2001-ben adta ki először egységes osztályozási rendszerét „Funkcióképesség, fogyatékosság és egészség nemzetközi osztályozása” (International Classification of Functioning Disability and Health, ICF) címmel.

Az ICF összeállításakor - a korábbi rendszerektól eltérôen - kifejezett hangsúlyt fektettek arra, hogy a rendszer deficit- és erooforrás-orientált legyen. Ennek következtében különösen jól alkalmazható a rehabilitáció terén. További értéke abban rejlik, hogy a klasszifikációs folyamatba bevonja az érintett személyt, tehát kifejezetten kliensközpontú osztályozásnak tekinthetố. Tételei több szintbe és alszintbe rendezôdnek, és a hétköznapi élet minden területére kiterjednek. Segítségével így átfogó leírás készíthetổ a szóban forgó személy állapotáról.

\section{Kliensközpontú szemlêlet}

A kliensközpontú szemléletból adódóan a felhasználóval együtt határozható meg, hogy az illetố személy élete mely területein nem érzi kielégítônek a részvételét, melyekben kíván jobban részt venni annak érdekében, hogy teljesebb életet élhessen, és mire van szüksége e cél eléréséhez. A szükségletein emberi vagy szakmai segítséget is érthetünk, de idesorolható a segítố technológiák alkalmazásai is. Az ICF skálázási rendszere segítségével nyomon követhetô az is, hogy a beavatkozás, az ST-alkalmazás milyen sikerrel jár, mennyire javít a személy helyzetén.

Az ICF-nek a korábbi rendszerekhez viszonyított legnagyobb eltérése azonban abban rejlik, hogy az ICF klasszifikációjának középpontjában nem a betegség vagy fogyatékosság, hanem maga a beteg vagy fogyatékkal élő személy áll. Ahogy a használhatósági szakemberek a felhasználóval együtt tervezik meg az egyes szoftverek által nyújtott felületet, a rehabilitációs szakemberek a klienssel kommunikálva, vele együtt tervezik meg a terápiát. A rehabilitációs folyamat kliensközpontúsága párhuzamba ál- 
lítható az informatikai rendszerek felhasználó-központú tervezési folyamataival. Úgy is fogalmazhatunk, hogy a használhatósági szakemberek kliensközpontú informatikát szándékoznak megvalósítani.

Az ICF-rendszer segítségével az egyes személyeknek nemcsak a deficitjei ragadhatók meg, hanem a jól funkcionáló képességei, életkörülményei és ezek változásai is leírhatóvá válnak. Az ICF különösen sok teret hagy az esetek egyedi sajátosságainak leírására, s ebból adódóan igen összetett, sokszintủ klasszifikációs rendszer. Mivel nem kizárólag orvosi szemléletû, az élet minden területére kiterjedő leírást is lehetôvé tesz, és szerves részét képezik az életvitelt segítő ST-alkalmazások is.

Az ST fejlôdésének korai, általunk „laboratóriumi”-nak nevezett szakaszában kevés figyelmet szenteltek a felhasználók helyzetének. Az ICF a fogyatékosság és a meglevố képességek leírása mellett az elemzett személy életkörülményeit is nagy részletességgel számba veszi. Ahogy azt a WHO 1946-ban elfogadott alkotmányának elsố paragrafusa kimondja, az egészség nem a betegségek hiánya, hanem a testi, lelki és szociális jólét (Forgács 2000). A szociális, családi és fizikai környezet nagyban meghatározza az ember életvitelét és lehetséges rehabilitációjának irányát. Ezzel párhuzamosan a megfelelő ST-alkalmazás kiválasztásánál is figyelembe kell venni, hogy valakinek van-e segítsége az adott eszköz használata során, fekve, ülve, esetleg kerekes székben használhatja-e az eszközt, az adott szolgáltatás telepíthetố-e a lakásába, mennyiben javítja az életminóségét, ha a házon belül használja, vagy leginkább a lakóhelyén közlekedve lenne rá szüksége. Az ICF segítségével jól megragadhatóvá válik a kontextus rendkívül összetett és egyedi konfigurációja, melyben több tényezô egyszerre tud érvényesülni.

\section{Az ST kategorizálása az ICF-ben}

Az ST tekintetében az ICF a következő felosztási lehetôségeket kínálja:

1. Olyan technológiai eszközök, amelyek egy bizonyos funkcionális vagy strukturális fogyatékosságot kompenzálnak (pl. hallókészülék, retina implantátum, bionikus végtagprotézisek stb.);

2. Olyan alkalmazások, amelyek bizonyos aktivitásokban segítenek (pl. honlapfelolvasó program, szájjal mozgatható kerekes szék stb.).

E két csoport kapcsán fontos megemlíteni, hogy ICF különbséget tesz az „aktivitás” és a „participáció” között. Aktivitásnak azt nevezik, amire képes az illetô, participációnak pedig azt, amit ténylegesen meg is tesz, vagyis életének azok a területei tartoznak ide, amelyekben valóban részt vesz. Például egy kézamputált korlátozott az írásban, a tárgyak manipulálásában stb., de egy mozgatható protézis segítségével ezekben az aktivitásokban részt tud venni. A kettô különbségéból adódik a rendelkezésre álló erőforrás, illetve akadály. Az ST szerepe tehát az eróforrások növelése, amennyiben az illetố személy tud és akar élni ezekkel a lehetôségekkel.

Az ST-eszközök harmadik típusát a felhasználói kontextus határozza meg. Ilyenek például a kerekesszék-liftek az akadálymentesített épületekben.

Az ICF-klasszifikáció szerint az ST-eszközök alkalmazásának három fố területét különböztethetjük meg: a kommunikáció fogadását, a kommunikáció produkálását, és a környezettel való interakciót segítô alkalmazásokról beszélhetünk. 


\section{Az eszközök és a felhasználók képességeinek közös osstályozása}

Az ICF szemléletével az ST-alkalmazások az emberekhez hasonlóan osztályozhatók. Ahogy az embereknek is vannak percepciós, kommunikációs stb. deficitjei, illetve képességei, úgy a kifejlesztett alkalmazásoknak is vannak olyan kvalitásai, amelyek az emberekhez hasonlóan leírhatóak a rendszerrel (Billi et al. 2006). Emberek és gépek (technológiai eszközök) közös klasszifikációja elsố hallásra talán futurisztikusnak tûnik, de mivel az adott eszköz egy speciális képesség vagy tevékenység pótlására, segítésére készült, magától értetốdó, hogy az adott deficit besorolásával megegyező „képességgel" kell rendelkeznie a kiváltó vagy segítô technológiának is. A szemléletból adódóan a hipotetikus „,ideális” alkalmazásnak minden olyan tulajdonsága meg kell legyen, mint egy átlagembernek. A felhasználók és az alkalmazások közös klasszifikációja azt a jövő́képet vetíti elóre, amikor az IKT-alkalmazások intelligenciája, a felhasználókhoz való alkalmazkodási képessége eléri azt a szintet, hogy nem eszközként, hanem partnerként kezelhetók, vagyis nem csupán szúk tartományú feladatok elvégzésében segítenek, hanem - esetleg emberi nyelven - kommunikálhatunk, együttmúködve velük, céljaink elérése végett.

\section{Az ISO és más rendszerek szerinti klasszifikáció}

Az ICF-rendszer ugyan már komoly múltra tekinthet vissza, de egyelóre még kevéssé elterjedt az ST-szakemberek körében. A következókben röviden áttekintjük a jelenleg is használatos különféle klasszifikációs rendszereket.

Az úgynevezett réselmélet (Chilkó 2007) szerint két módon lehet a speciális tulajdonságokon, fogyatékosságokon változtatni. Az egyik módszer az eszközök használatához szükséges követelmények csökkentése: ez a design for all, azaz a mindenki számára alkalmas tervezés. Itt a tervezók a teljes felhasználói bázis számára alakítják ki a termékek használhatóságát, bevonva a fogyatékkal élô speciális felhasználókat is az adott termék felhasználói körébe. A mozgalom alapeszméje az integrált használat: nem különítik el a két csoportot, külön szolgáltatásokat állítva elố számukra, hanem megpróbálják elôsegíteni a fogyatékkal élók és az átlagosnak tekinthetô emberek közös életvitelét. A réselmélet másik módszere az orvosi terápiák és segédeszközök alkalmazása. E szerint a rehabilitáció és a terméktervezés terén elfogadott elmélet szerint az egyén funkcionális képességei és a termék múködtetésekor elvégzendố feladatok követelményei közötti távolság áthidalása a tervezố feladata. Ennek a „résnek” a legyốzése, a távolságot jelentố problémák optimális megoldása a speciális felhasználók számára történó ST-tervezés igazi kihívása.

A „Fogyatékkal élő személyek múszaki segédeszközei: Osztályozás és szakkifejezések gyújteménye” (MSZ EN ISO 9999:2003) szabványban leírtak szerint a segítố technológiák körébe sorolható bármely termék, berendezés, felszerelés vagy múszaki rendszer, amelyet fogyatékos emberek használnak, továbbá bármely egyedi gyártású vagy tömegtermék, amely megelốzi, ellensúlyozza, megszünteti vagy semlegesíti a károsodást, a fogyatékosságot vagy a hátrányos helyzetet. 
Az átlagostól eltérő képességú vagy tulajdonságú személyeket nevezzük speciális felhasználóknak. Ôk a következố csoportokba sorolhatók:

- siketek és nagyothallók,

- vakok és gyengén látók,

- némák és beszédfogyatékosok,

- pszichológiai, neurológiai és értelmi fogyatékosok,

- mozgáskorlátozottak,

- gyermekek,

- idôsek,

- átmenetileg (pl. terhesség miatt) megváltozott képességúek,

- átlagostól eltérố testméretúek.

A segédeszközöknek az ISO 9999 szabvány által meghatározott besorolási kategóriái az alábbi három fố csoportot különböztetik meg:

- testközpontú segédeszközök (pl. pacemakerek, lélegeztető- és hallókészülékek),

- tréninghez, képességfejlesztéshez felhasználható segédeszközök (pl. speciális szoftverek, játékok),

- a mindennapi élethelyzetekben segítő problémamegoldó segédeszközök.

Ezzel a csoportosítással olyan nemzetközileg is elfogadott megközelítés terjedt el, ami a fogyatékosságra való koncentrálás helyett a funkcionalitást helyezi a középpontba. Ebból az irányból megközelítve az ST körében különbséget tehetünk a kommunikációt, a látást, a számítógép-használatot, a mindennapi életvitelt, a tanulást, a mobilitást és általában a mozgást, a szórakozást és a rekreációt segítố alkalmazások és szolgáltatások között.

A kommunikációt segítô alkalmazások közé többek között az alternatív beszéd- és a hallássegítô rendszerek tartoznak. Ilyenek a kommunikációs táblák, beszéd-szintetizátorok, lézeres mutatók, Braille-eszközök, hordozható (és egyéb módosított) írógépek, jegyzetelő eszközök.

A látást a különféle nagyító berendezések segítik (pl. a zártláncú videohálózatok nyomtatványok kinagyítására is alkalmazhatók, afféle digitális nagyítóként használva a kamerát és a nagyméretú kijelzốt). Ezt a funkciót támogatják a beszélő készülékek (pl. órák, számológépek), a könyvtartók és lapozók, a hangoskönyvek és a Braille-írást használó dokumentumkezelók.

A számítógép-használatot könnyítik meg az alternatív bemeneti és kimeneti egységek, valamint az akadálymentesített szoftverek. Idesorolhatók a Braille-alapú kimeneti és bemeneti egységek (szövegbevitelre és olvasásra alkalmas eszközök, nyomatatók), a beszédfelismerố és beszédgeneráló szoftverek, az érintóképernyók, a szavakat elôre felajánló virtuális (képernyốn megjelenô) billentyűzetek, az ergonomikus bútorok és eszközök, pl. az ismétlődő megterhelések okozta sérülések (Repetitive Strain Injury, $R S I$ ) ellen védelmet nyújtó, morzekódon alapuló beviteli egységek és az operációs rendszerek beépített akadálymentesítô lehetôségei.

A mindennapi életben a táplálkozást, ételkészítést, tisztálkodást, öltözködést, házimunkát támogatni lehet különleges étkészletekkel, mechanikus vagy intelligens robottechnológiát használó adagoló szerkezetekkel. Idetartoznak továbbá a fürdő́felszerelések, a riasztók (figyelmeztetók, füstjelzók), az esetenként a felhasználó mozgását 
figyelembe vevố világítástechnikai berendezések, a liftek, az otthonautomatizálási rendszerek és az akadálymentes épületek is.

Vannak olyan ST-rendszerek, melyek a tanulást, a memóriát, az önkifejezést segítik, az asszociációs képességet, a problémamegoldást fejlesztik, vagy egyéb kognitív tréninget lehet velük végezni. Ezekre jó példák az adaptív gyermekjátékok, a vizuális gondolkodást támogató szoftverek és a tantermi oktatást moderáló, asszisztáló rendszerek.

A mobilitás és általában a mozgás megkönnyítésére a sétálást és lépcsôzést segítô ST-rendszerek alkalmazhatók: itt a kerekes székek és a használatukat segítő eszközök, a végtagokat helyettesítő gépek és az adaptált kerékpárok jelenthetnek megoldást. A mobilitásban további segítséget nyújthatnak az autóvezetést támogató adaptív berendezések (távolságtartás, sebességkorlátozás) és az egyedi igényekre felkészített gépkocsik (pl. speciális kormányzás és sebességváltás, beszálláshoz emelő alkalmazása) mindezek teljesebbé teszik a speciális felhasználók életét.

A szórakozást és rekreációt lehetôvé tevố eszközök a sportban, a kultúrában és a társadalmi életben fejtik ki hatásukat. Ilyenek a hallássérültek számára készített filmfeliratozások, a videojátékokhoz készült kiegészítôk, a futást vagy akár a horgászást támogató eszközök.

Az újszerú, modern segítố technológiák (robotika, nanotechnológia) a jövóben egyre jobban elmossák az organikus és a nem organikus rendszerek közötti határokat, és tovább fogják növelni a fogyatékkal élók lehetôségeit. A jelenleg is folyó kutatások nyomán olyan, különféle szerveink múködését pótoló megoldások elterjedése várható, mint a látássérültek retinaimplantátumai vagy a bionikus végtagokkal való érzékelést lehetővé tevő, receptorokat helyettesítô szenzoroknak az idegrendszerrel való összekapcsolása. Az ilyen és ehhez hasonló technológiák részben máris rendelkezésre állnak, s így egyre közelebb kerülünk a transzhumán emberképhez, ami nemcsak a fogyatékkal élók deficitjeinek pótlását, hanem a hagyományos emberi képességek meghaladását is jelenti (Ettinger et al. 2005).

\section{Segítő technológiai alkalmazások}

A felsorolt osztályozásokon túl az alkalmazások sorra vételekor fontosnak tartunk még egy további lényeges szempontot bemutatni. Az egyes eszközök múködhetnek különállóan, bizonyos korlátozott funkciókat betöltve, illetve a környezetbe integráltan egységes szolgáltatásokkal sokrétû́ segítséget nyújtva a felhasználónak.

A következókben a teljesség igénye nélkül példákat hozunk mindkét rendszertípusra. Egyfelól a piacon kapható termékek bemutatására törekszünk, másfelól olyan, egyelőre még csak kísérleti jelleggel múködő rendszerekról is szót ejtünk, amelyek elóremutató nézôpontot képviselnek, vagy szerintünk a jövóben fontossá váló szolgáltatást nyújthatnak a fogyatékkal élók és az idôsek számára. A magyarországi fejlesztések sokszor kevés publicitást kapnak, ezért megismertetésük érdekében a hazai példákra helyezzük a hangsúlyt. 


\section{Környezeti intelligencia}

Az informatikai rendszerek fejlódési iránya sok szempontból azt mutatja, hogy a számítógépek a jövóben nem csupán valamely adott helyen levố eszközök lesznek, hanem olyan intelligens környezetben fogunk élni és dolgozni, amely alkalmazkodik szokásainkhoz, érzékeli igényeinket és tartózkodási helyünktól függóen lép velünk interakcióba. Az ilyen rendszerek egyik legfontosabb alkalmazási területe az egészségügy. Az egészséggel kapcsolatban régóta halljuk a médiából, hogy a hangsúly áttevődik a kórházi ápolásról az otthoni ellátásra, a beavatkozásokról az életminôség javítására, a gyógyításról a megelőzésre. Ezekkel a trendekkel párhuzamosan egyre nagyobb szerephez jutnak a környezetbe ágyazott egészségügyi rendszerek, amelyek az egészség, illetve az erônlét megốrzése és a kórházba kerülés elkerülése érdekében képesek orvosi távfelügyeletet biztosítani, visszajelzéseket és tanácsokat adva a felhasználónak. Az informatikai kutatásnak ezt a területét kezdetben az „eltûnố számítástechnika” (disappearing computing), késóbb a „környezeti informatika” (ambient computing), valamint a „mindenütt jelen levô”, illetve a „mindent átható számítástechnika” (ubiquitous, illetve pervasive computing) megnevezéssel különböztették meg. A négy különbözố megnevezés lényegileg nem tér el egymástól, de jól jelzi a témára irányuló érdeklődés mértékét.

Az ST területén a környezeti intelligencia legfontosabb felhasználói a krónikus betegségben szenvedók, akik nem igényelnek állandó kórházi ellátást, viszont az otthoni ápolásuk szempontjából lényeges a folyamatos monitorozásuk. Az önellátásra csak részben képes, egyedül éló személyek életvitelében szintén lényeges szerepet tölthetnek be ezek a rendszerek, mivel nekik ugyan csupán bizonyos feladatok elvégzéséhez van szükségük támogatásra, viszont ha kritikus szituáció áll elő, gyakran nem képesek segítséget hívni.

Jóllehet az ST szempontjából vannak különbségek a fogyatékkal élók és az idősek között, ez a két felhasználói csoport mégis együtt kezelendô. A két kör problémái nagyon hasonlók: az idôseknek is korlátozott képességeik vannak csakúgy, mint a fogyatékkal élóknek, legyen szó akár kognitív, akár mozgásos vagy más egészségügyi problémákról. A két csoport közötti különbség a technológiai eszközök iránt tanúsított attitûdökben mutatkozik meg. Míg a fogyatékkal élók kortárscsoportjaikhoz igazodó szociális normái szinte elóírják bizonyos informatikai eszközök vagy szolgáltatások (pl. mp3 lejátszók, internetes szolgáltatások stb.) használatát, addig az idốseknél ezek a normák jelentốsen eltérók lehetnek (pl. headset használata mobiltelefonnál). Ugyanakkor az idősek sokkal kevésbé érzékenyek az adatbiztonság és a személyiségi jogok kérdéseire, ha az adott szolgáltatás növeli általános biztonságérzetüket. A kamerával múködô automatikus elesés-detektáló rendszereket például a fiatalabb és ebból adódóan az új technológiák iránt nyitottabb mozgáskorlátozottak nagyobb arányban utasítják el, mint idősebb társaik, még akkor is, ha a rendszer nem állandóan közvetít képet a központi orvosi szolgálatnak, csak detektált vészhelyzet esetén.

A „mindent átható” informatikának az ST területén háromféle hatókörét különböztethetjük meg attól függóen, hogy a technológia segítségével orvosolt probléma mennyire akut. A legbelső körbe tartoznak a legfontosabb funkciókkal felruházott, sürgősségi segítséget nyújtó alkalmazások. Ilyenek például a már említett elesés-detektáló 
rendszerek és a szívbetegek által használt folyamatos vagy idốszakos EKG-elemzô alkalmazások. Ezek a rendszerek egy átlagos orvosi vizsgálatnál hosszabb ideig monitorozzák a pácienst, és így akár előre is figyelmeztethetik ốt és orvosát egy esetleges vészhelyzet bekövetkezésére. A környezetbe integráltan szükség esetén orvosi segítséget is hívhatnak, illetve a felhasználójuk számára kedvezó formában módosíthatják a környezeti tényezóket (pl. a megfelelố helyen felkapcsolhatják a világítást).

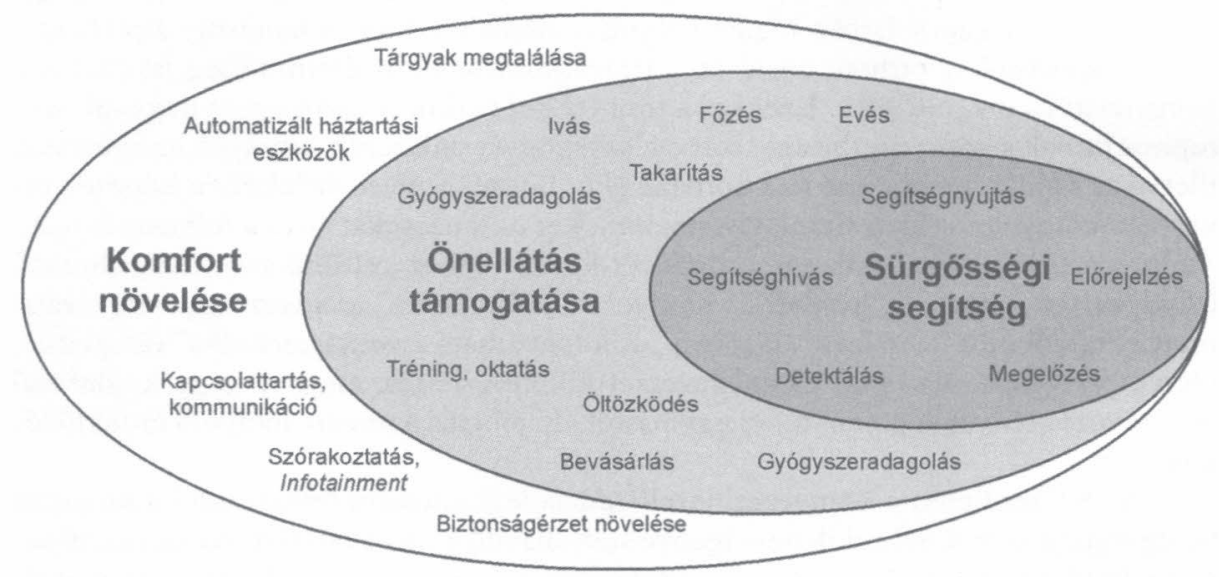

Jeffrey Hightower nyomán (Laufer 2006)

A következó körbe azok a szolgáltatások tartoznak, melyek a hagyományos értelemben vett egészségi állapot szempontjából kevésbé fontosak, ám az életminőségre pozitív hatást fejtenek ki. Az élettel való elégedettség hosszú távon jelentôs hatást gyakorol a fogyatékkal élő egészségi állapotára, a „másságának” az elfogadása, a problémájával való megküzdési stratégiáinak sikere nagyban múlik azokon a szolgáltatásokon, melyek időszakos ápolói segítséggel kiválthatók ugyan, de automatizálva lehetőséget adnak az önálló életvitelre.

Érdekes paradoxonhoz vezet a technológia ily módon való felhasználása: míg a fogyatékkal éló személy korábban az ápolóitól függött, az eszköz használatával az adott szolgáltatástól vagy terméktól válik függớvé. Az önellátás támogatása azoknak fontos, akik nem tudnak maguknak fő́zni, nem képesek egyedül táplálkozni, nem tudják elvégezni a házimunkákat, illetve a környezetükben való mozgásnál is segítségre szorulnak. Az emlékezeti problémákkal küzdó, fóként idôs kori dementiában szenvedő emberek esetében nagyon fontosak a gyógyszeradagoló rendszerek, melyek kiporciózzák és figyelmeztetik az illetốt az orvosság bevételére. Ez sok egyedül élő idős személy esetében fontos segítségnek bizonyul.

A harmadik körbe azok az alkalmazások tartoznak, melyek nem létfontosságúak, és az önellátáshoz sem feltétlenül szükségesek, egyszerúen csak a fogyatékkal élók komfortérzetét növelik. A pszichológiából ismert Maslow-féle szükséglethierarchia-modellnek megfelelően a fiziológiai és biztonsági szükségletek kielégítése után más, magasabb rendú (pl. szociális) szükségletek kielégítése is fontossá válhat. A komfortérzet növelésé- 
re szolgáló ST-rendszerek alkalmazásának feltétele, hogy a korábban említett két csoportba tartozó szolgáltatások már a felhasználó rendelkezésére álljanak vagy ugyanabba, vagy egy másik jelen levô ST-rendszerbe integrálva. A felhasználó csak akkor fogja igazán értékelni a másokkal való kommunikáció vagy a szórakoztató elektronikai eszközök révén számára megnyíló új lehetốségeket, ha egészségét tekintve biztonságban érzi magát, és az önellátáshoz szükséges alkalmazások is a rendelkezésére állnak.

\section{Az emberi test mint átjátszó egyuség}

A környezeti intelligencia alapvetố problémája, hogy a háttérben megbúvó informatikai rendszer akkor tud alkalmazkodni a felhasználóhoz, és reagálni annak szükségleteire, ha cselekvéseiról vagy pszichológiai és testi állapotáról pontos információt szerez. A szükséges információnak csak egy részéhez tudunk a testtel való érintkezés nélkül - például kamerás felismeréssel vagy a lakásban elhelyezett mozgásérzékelókkel - kívülról hozzáférni. A fontosabb, sokszor kritikus információk (hốmérséklet, EKG, bő́rvezetés stb.) többnyire kizárólag a testen elhelyezett szenzorok segítségével nyerhetók ki. A testen elhelyezett szenzorokhoz csatlakoztatott adatátviteli egység energiafelvétele és ebból adódó üzemideje jelentősen korlátozza a használat idôtartamát. A szenzorok egyedi felhelyezése és viseletük kényelmi jellemzói döntőek lehetnek a testen hordott egység, így az egész rendszer sikere szempontjából. További probléma, hogy több felhasználós környezetben az érzékelố rendszer nem tudja megkülönböztetni egymástól a felhasználókra szerelt szenzorokat.

Egy mostanában kialakult kutatási terület részben megoldást jelent az imént felsorolt problémákra. A kutatók több helyen (pl. a Philips cégnél) olyan szenzorrendszert fejlesztettek ki, amely a felhasználók testét információt közvetítő közegként használja fel. A testre szerelt átjátszó egység olyan gyenge elektromos teret hoz létre a testen, ami lehetôvé teszi bizonyos mennyiségú adat átvitelét. Ezt nevezik a kutatók aktív digitális aurának. A mező az emberi test néhány centiméteres körzetében él, így az esetek túlnyomó többségében elkerülhetố, hogy különbözố személyek szenzorai interferáljanak egymással. A különbözó funkciójú szenzorokat a testre szerelt átjátszó egységhez (Body-Coupled Transceiver) csatlakoztatják, amely vagy önállóan, vagy egy másik készülék (például mobiltelefon) segítségével továbbítja az adatokat az egészségügyi központhoz. Bizonyos rendszer-architektúrákban a környezeti informatikai rendszer alapegysége a testkörnyéki hálózat (Body Area Network, BAN), amely a közismert helyi hálózatokhoz (Local Area Network, $L A N$ ) hasonlóan összesíti a testról szerzett információt. A BAN-ok valamilyen speciális közbülsố szintû központon keresztül kapcsolódnak egy egészségügyi központhoz, ahonnan a jogosultsággal rendelkező orvosok le tudják kérni az információt.

\section{Ambiens világitó rendszer}

Az Európai Unió 6. keretprogramja által támogatott Aladin (Ambient Lighting Assistance for an Ageing Population) elnevezésú projekt keretében intelligens otthoni alkalmazásként olyan ambiens világító segédrendszert hoztak létre a kutatók idősek számára, 
amely a felhasználók szükségleteihez igazítja a világítást. Az eszköz kidolgozásában a Budapesti Múszaki és Gazdaságtudományi Egyetem Ergonómia és Pszichológia Tanszéke is részt vett. A rendszer felhasználói - elsősorban egyedül élő idôs emberek - különféle szenzorokat viselnek, melyek továbbítják fiziológiai adataikat (pulzus, bőrvezetési szint) a központi egységnek. Ezekból az adatokból különbözố algoritmusokkal következtetnek arra, hogy az adott tevékenységhez milyen világítási körülmények a legmegfelelóbbek. Ahogy változnak a testi jelek, úgy változik a megvilágítás mindaddig, amíg az adott személy számára az általa végzett tevékenységhez megfelelő értékeket el nem éri. A rendszer fontos részét képezi egy bio-feedback alkalmazás, ami a relaxáció elsajátításában segít, valamint egy kognitív tréning-programcsomag, amely a koncentrációs és problémamegoldó készségek szinten tartásában támogatja az idôs felhasználót.

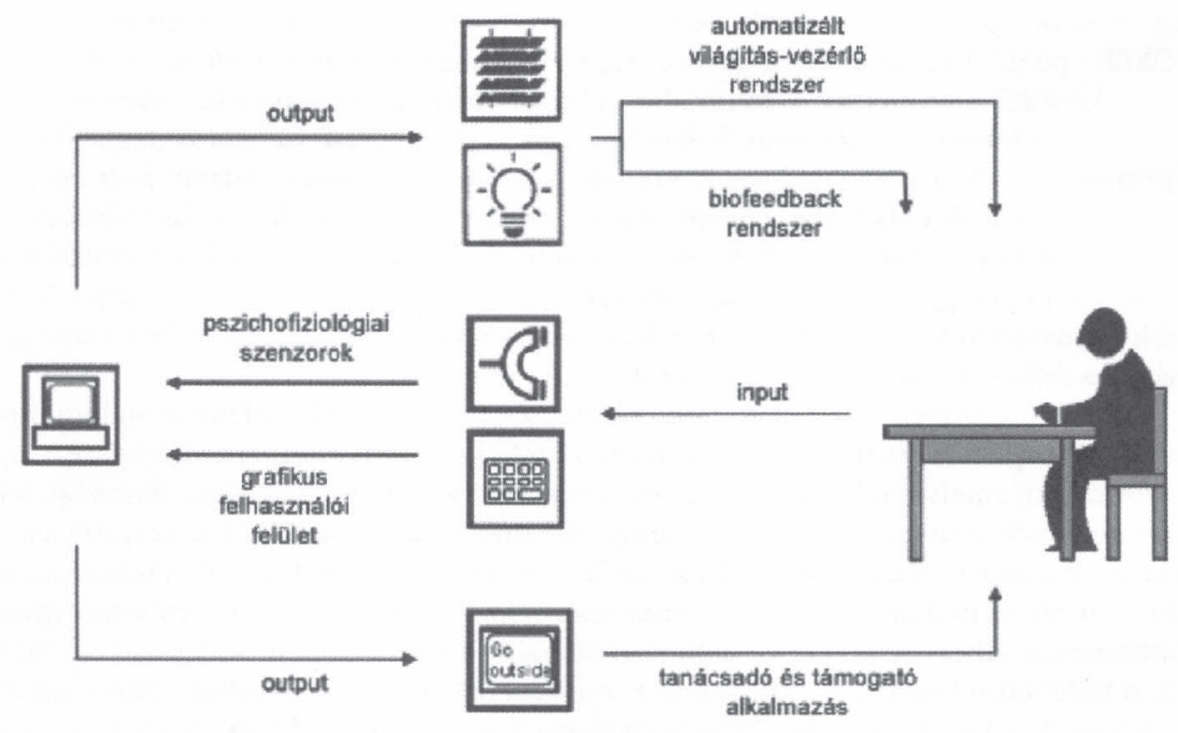

Aladin ambiens világító segédrendszer idôsek számára

A világítás jellemzôi (a színhômérséklet, a fényerôsség és a szín) jelentős hatással lehetnek a pszichés jóllétre, különösen olyanok esetében, akik idejük nagy részét egyedül töltik a lakásukban, mesterséges fény mellett, esetenként rossz világítási körülmények között. A nap folyamán minket érố világítás döntốen befolyásolja a circadian ritmust. Ennek defektusai fontos szerepet töltenek be az alvászavarok létrejöttében, melyek az idôsek esetében gyakori problémaként jelentkeznek, és sokszor hozzájárulnak a depresszió kialakulásához. Az ambiens adaptív világítórendszerek a fény paramétereinek megfelelő kalibrálásával középtávon normalizálni képesek a circadian ritmust, hozzásegítve az időseket az egészséges alvási ciklushoz és a jobb közérzethez. 


\section{Hazai múhelyek}

Magyarországnak a környezeti intelligencia terén folyó fejlesztési programokhoz nélkülözhetetlen orvostechnika mellett a mérés- és irányítástechnikában, valamint a távközlésben is komoly hagyományai vannak. A Neumann János Számítógép-tudományi Társaság (NJSZT) - hasonló tárgyú nemzeti stratégia és program kezdeményezéseként 2005 októberében Hanák Péter vezetésével létrehozta a „Beágyazott és ambiens rendszerek innovációs múhelyét" (BeAm-IM). Az információ-kommunikáció, a telemedicina és az ambiens intelligencia összekapcsolt felhasználására az életvitel szolgálatában „EVITA” (eletviteli technológiák és alkalmazások) címmel javasolt programjukat megalapozó tanulmányt 2007-ben bocsátották nyilvános szakmai vitára. Azóta a Budapesti Múszaki és Gazdaságtudományi Egyetemen létrehozták az Egészségügyi Mérnöki Tudásközpontot, amely többek között a környezetbe ágyazott egészségügyi rendszerekkel foglalkozó hazai szervezetek és múhelyek kutatásainak összehangolásáról és a társadalomnak az ilyen irányú fejlesztési eredményekról való tájékoztatásáról gondoskodik.

A Budapesti Múszaki és Gazdaságtudományi Egyetem és a Magyar Tudományos Akadémia Péczeli Gábor professzor vezetésével közös kutatócsoportot állított fel a beágyazott információs technológiai rendszerek kutatására, amely szintén régóta végez ilyen irányú fejlesztési tevékenységet.

A hazai kutatók érdeklódését a kutatócsoportok nagy száma mellett az is jól mutatja, hogy az NJSZT innovációs múhelye, a BeAm-IM által 2007-ben „AmDemo: ambiens rendszerekkel segített életvitel a gyakorlatban” címmel szervezett konferencia sikere nyomán 2008-tól évente megrendezik az „EVITA: Infokommunikáció az életvitel szolgálatában" elnevezésû szakkiállítást és vásárt.

\section{Intelligens eszközök}

A környezetbe ágyazott rendszereken kívül vannak természetesen különálló eszközök is, melyek egy-egy funkciót látnak el. Rengeteg ilyen eszköz létezik, az időseknek készített mobiltelefonoktól az autisták számára megalkotott érzelemkifejezố avatárokon át a feledékenység leküzdését segítố „intelligens” kulcsokig. Terjedelmi korlátok miatt nem áll módunkban részletesen tárgyalni ezeket az eszközöket, így csak három általunk különösen fontosnak tartott eszközcsoportot mutatunk be röviden. A fogyatékkal élớk mindennapjaiban talán a speciális bemeneti és kimeneti eszközök töltik be az egyik legfontosabb szerepet. Az ST részterületei közül az agy-számítógép interfész áll leginkább a tudományos érdeklődés középpontjában. A bionikus végtagok és érzékelók pedig a tudományos fantasztikus irodalom világát hozzák el a jelenbe, ahol ezek az eszközök már rendelkezésre állnak, és sikeresen használják is óket.

\section{Speciális bemeneti és kimeneti essközök}

A speciális ki- és bemeneti egységek a felhasználók képességeihez igazodva teszik lehetôvé a számítógép felhasználását. Ezeknek az egységeknek a múködésénél sokszor találkozunk a képernyőn megjelenő virtuális billentyưzetekkel vagy virtuális 
kommunikációs táblákkal. Az elóbbiek a szokványos karaktereken kívül az elsóként beütött betú alapján javaslatot tesznek egész szavakra is, ily módon segítve a gyorsabb szövegbevitelt (KeyStrokes 4.0), az utóbbiak pedig a különböző célcsoportok (gyermekek, felnốttek) igényeinek megfelelő grafikus elemekkel tûzdelt programok, amelyeknél piktogramokkal történik a kommunikáció.

Az ELTE TTK neurális információfeldolgozó kutatócsoportja Lőrincz András vezetésével fejlesztette ki a „fejegér” elnevezésű eszközt (Lorincz et al. 2004). A fejegér olyan képfeldolgozó szoftverre épül, amely az arc egyes jól kivehető pontjait figyelve vezérli a képernyốn megjelenố kurzort. A kijelző felületén megjelenő gombok segítségével rövid, hangos üzenetek közölhetốk, a gép „kommunikációs táblaként” üzemelhet. A kommunikációs táblán elốre megfogalmazott rövid szövegek szerepelnek: köszöntés, bemutatkozás, hangulati állapotok kifejezései. A használatba vételt megelőzően játékos szoftverek motiválják és tanítják a speciális felhasználókat az eszköz használatára, mert a mozgásukban súlyosan korlátozottak számára kezdetben a képernyốt félig betöltố gomb eltalálása is komoly erôfeszítést igényelhet.

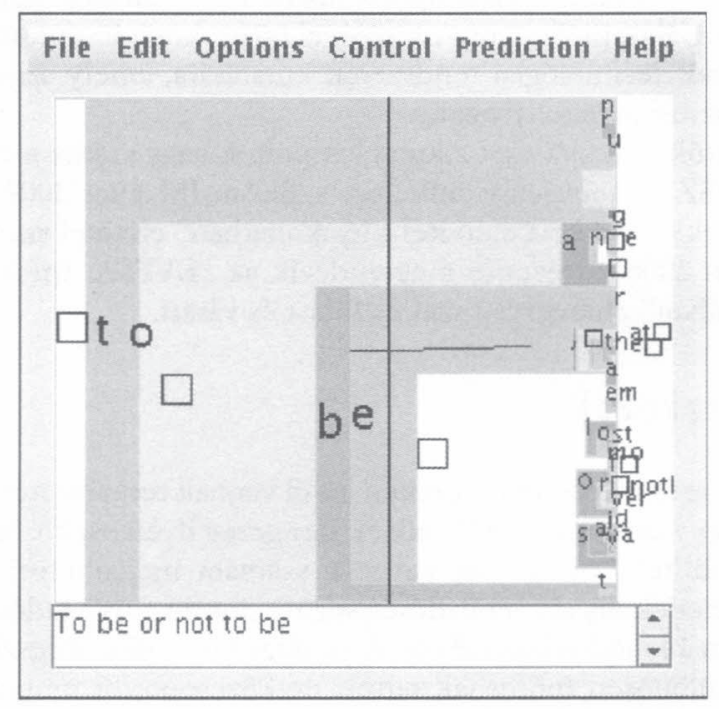

Dasher szövegbeviteli rendszer

A Cambridge-i Egyetemen a David MacKay vezette Inference kutatócsoport hozta létre a Dasher szövegbeviteli szoftvert, amely billentyúzetelérés nélküli környezetben biztosít kommunikációs lehetốséget. A program alapkoncepciója abban áll, hogy a kurzort a jobb oldalról megjelenó betúk felé pozicionáljuk, és a betúk, illetve szavak előfordulásának gyakorisága alapján a szoftver „kitalálja”, melyik karakter következhet. A szoftver elérhetố az egér vagy joystick használatával is, de vannak olyan kreatív megoldások is, mint például egy piros golflabda mozgatása egy kamera elótt vagy a szemmozgás követése. Ezekkel a módszerekkel befolyásolni tudjuk a folyamatosan mozgó betúk áramlási irányát, és szavakat írhatunk ki az eszköz segítségével. A kutatók szerint 
némi gyakorlással el lehet érni a normál billentyưzeten való gépelés átlagos sebességét (29 szó percenként).

A számítógép vezérlésére szolgáló legnépszerúbb eszköz az egér, melynek használatát gyakran meggátolja a kézremegés: egyes kutatások szerint az USA-ban tízmillió, az Egyesült Királyságban közel 3 millió fố küzd ezzel a problémával. E gátló tényezố kiküszöbölésére hozta létre az IBM a segító egéradaptert, amely kompenzálja a kézremegésból adódó pontatlanságot, és képes kiszúrni a véletlenszerú többszörös kattintásokat is.

Japánban fejlesztettek ki egy tapintással múködő, Braille-írást használó ki- és bemeneti egységet (Amemiya 2007). Ez egy furulyához hasonlító eszköz, amelyen Braillekarakterek alkotják a billentyúket, beleértve néhány fontosabb funkcióbillentyút is. A speciális felhasználó a két kezével tud szöveget bevinni, és az ujjaival érzékeli a képernyốn megjelenó betúket.

\section{Agyszámítógép interfész}

Az emberszámítógép interakció egyik legnagyobb közfigyelemben részesített területe az agyszámítógép interfész (Brain Computer Interface, BCI). A BCI valójában sokféle technológia együttes elnevezése, amelyek arra szolgálnak, hogy egy számítógép segítségével az agyra vagy az agyba szerelt szenzorok és jeladók révén bizonyos kognitív folyamatok közvetíthetók legyenek. A figyelem középpontjában azok a rendszerek állnak, melyekben a koponyára helyezett elektródokkal (EEG) és egy tanuló algoritmusokkal múködő számítógépi programmal bizonyos feltételek között „ki lehet találni”, hogy mire gondol az illetố. Az ilyen BCI rendszerek segítségével - bizonyos „tréning” után, melynek során a felhasználó megtanulja, hogy egyes dolgokra hogyan gondoljon, és a rendszer is megtanulja, milyen jeleket ad a felhasználó, amikor arra a bizonyos dologra gondol - az EEG jelekból meg lehet határozni, hogy az illetố a képernyố melyik részére néz éppen. Így végtagok nélküli, esetleg beszédképtelen személy is képes lehet arra, hogy levelet írjon, vagy más módon kommunikáljon a környezetével.

Míg ezt a módszert az ún. „nem invazív” megoldások közé sorolják, mivel itt csak a koponya felületére helyeznek elektródákat, az „invazív” BCI-alkalmazásoknál több elektródát építenek be a koponyán belülre. Az ilyen rendszerek is az elốzóekben ismertetett elven múködnek, csak pontosabb, jobb funkcionalitást tesznek lehetốvé.

A továbbiakban ismertetett bionikus eszközök közül az idegrendszerrel közvetlen kapcsolatban álló implantátumokat is a BCI-technológiák közé szokás sorolni.

\section{Bionikus eszközök}

A bionikus eszközök kialakítása során a tervezók kapcsolatot építenek ki az élố szervek és a mechanikus, illetve elektronikus rendszerek között. Segítségükkel pótolják a hiányzó testrészek funkcionalitását, vagy éppen új lehetôségekkel szolgálnak felhasználóiknak. A népszerú, modern bionikus múvégtagok leváltják a korábbi barátságtalan protéziseket, és képessé teszik birtokosukat emberibb interakciókra. A legtöbb ilyen irányú fejlesztést világszinten az Egyesült Államokban végzik, részben katonai 
célú felhasználásra. A fejlesztés több irányban halad: a meglevố vagy hasonló testrészek múködésének másolásával kívánják elérni, hogy minél természetesebb legyen a mozgás, és pótolni lehessen az elvesztett testrészt.

Az izlandi Össur cég Rheo Knee elnevezésú intelligens múlába igen sikeresen alkalmazható az egyik lábukat elvesztett személyek esetében, növelve magabiztosságukat és mobilitásukat. A rendszer komplex érzékelô rendszert és célszámítógépet használ, amely az ép láb mozgását folyamatosan elemzi, és a leíró adatokat vezeték nélküli kapcsolattal átküldi a hiányzó testrészt helyettesítố robotlábba. A Rheo Knee múláb dinamikus és természetes mozgást tesz lehetôvé: felhasználója képes lépcsôn járni, és az útjába esố kisebb akadályokat (pl. a földön levő dobozt) is át tudja lépni, illetve arrébb tudja mozdítani, ami a hasonló eszközökkel eddig nem volt lehetséges.

A világ egyik legnagyobb kutatási ügynöksége, az amerikai védelmi kutatási projekteket szervezô DARPA (Defense Advanced Research Projects Agency) közremúködésével fejlesztették ki az i-Limb újgenerációs múkart. Ezt a tulajdonosa nemcsak vezérelni tudja idegrendszerével, hanem az ideghálózatán keresztül közvetlen visszacsatolást is kap a kivitelezett mozdulatsorról. Nemcsak látja, hogy például sikerült megfognia a kiszemelt tárgyat, de érzi is. A robotkéz múködéséhez a mellkasban és a vállban található idegekre kell csatlakoztatni az érzékelóket, amelyek így természetes úton kommunikálnak a testtel. Az i-Limb képessé teszi tulajdonosát olyan apró és egyben igen pontos mozdulatokra, mint az evőeszközök használata, a nyakkendő megkötése, egy adathordozó lemez megfogása és behelyezése, nyomógombos telefon használata vagy akár egy puska megtöltése. A múvégtagok fejlesztése terén jelenleg a felhasznált nagy szilárdságú múanyagnak köszönhetốen könnyú, precíz és mégis robosztus $i$-Limb képviseli a legmodernebb technológiát.

A Dél-kaliforniai Egyetemen kifejlesztett Argus II rendszer szemüvegre szerelhetố kamerából, képfeldolgozó egységból és a szembe illesztett kb. hatvan elektródából áll. Segítségével a felhasználók nemcsak fényt és mozgást, hanem az igazi szemmel látotthoz nagyon hasonló képet fognak érzékelni. Ez a bionikus szem az elkövetkezó évek során fogja elérni azt a szintet, ahol már szélesebb körben is használható lesz, és segítségével az 55 év feletti korosztályban sûrún elôforduló szemfenéki meszesedés hatását, a retina sejtjeinek elhalását lehet majd ellensúlyozni.

Európában a német Fraunhofer Intézet Intellidrug rendszere megoldja a nehézkesen kivitelezhetô pontos és rendszeres gyógyszeradagolást. Ez a tesztelés alatt álló fog-implantátum mikrokontrollerból, mikroszenzorból, tartályból és mechanikus részból áll. Képes a megfelelô idốpontban kontrollált módon, akár távolról vezérelve a szervezetbe juttatni az előírt mennyiségú gyógyszert. Segítségével kizárható a beteg feledékenysége és a gyógyszer bevételének nehézségei is áthidalhatók, ráadásul a tartály könnyen újratölthetố.

\section{A segítő technológiák kritikus sikertényezői}

Az innovatív technológiák esetében különösen fontos számba venni azokat a tényezóket, amelyek a termék piaci sikerét vagy bukását eredményezhetik. Mivel a legtöbb ST-alkalmazás esetében nem már bejáratott termékek továbbfejlesztéséról, ha- 
nem jelentôs kutató és fejlesztố munkával létrehozott rendszerek piaci bevezetéséról van szó, a kritikus sikertényezók fontos szerephez jutnak ezen a területen.

A sikertényezốk egy fontos része a termék használatának költségével kapcsolatos: mérlegelni kell, hogy az installálás és a használatba vétel, a felhasználónak és környezetének kiképzése, a lakás vagy használati tárgyak átalakítása stb. összesen mennyibe kerül. A költségek hasznosulását mindig több szempont alapján, az életminôség javulását, a felhasználó személyes céljainak elérését, a funkcionális teljesítményt, a pszichoszociális hatásokat, a személy és a technológia közötti illeszkedést, valamint a felhasználó elégedettségét figyelembe véve határozzák meg (Gelderblom \& Witte 2002).

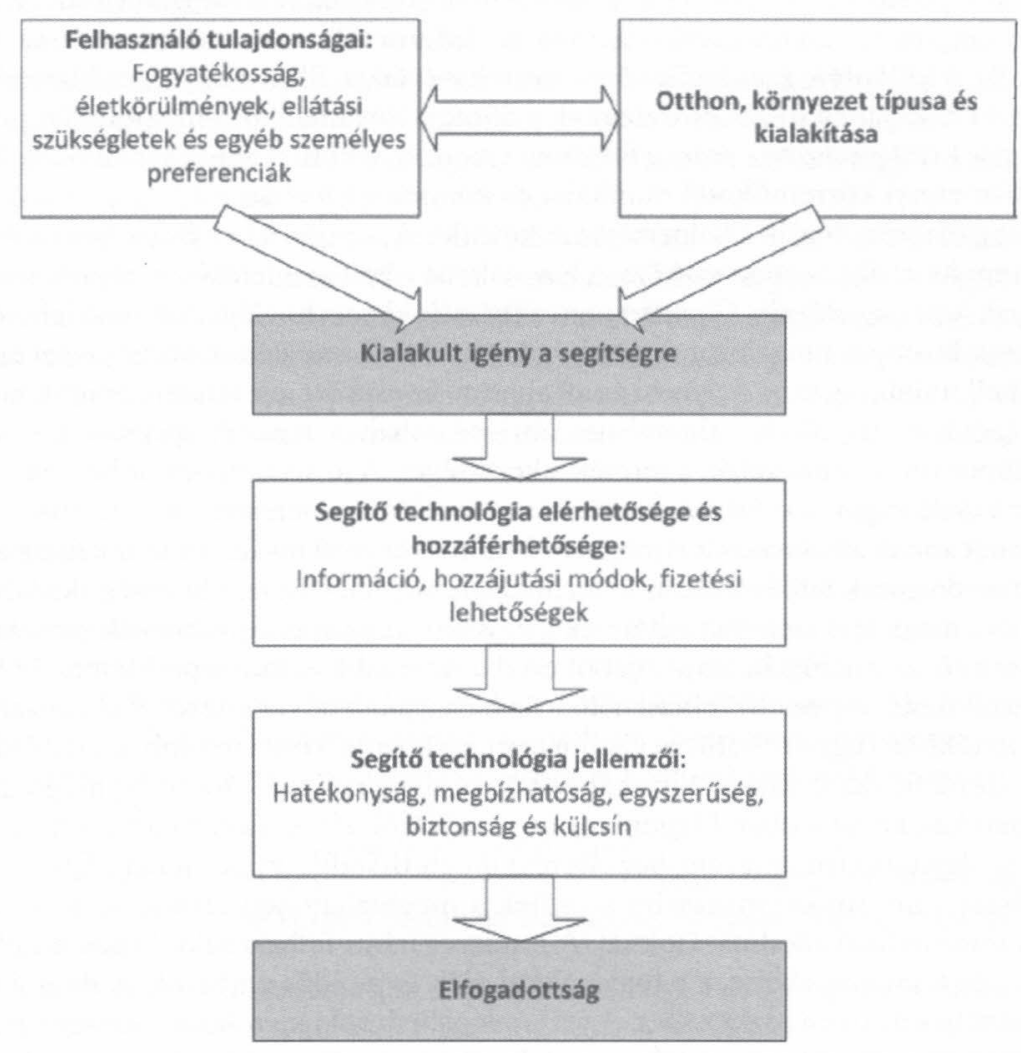

A segítő technológia elfogadottsága McCreadie és Tinker nyomán

Az ST elfogadottságát és a felhasználói elégedettség szintjét befolyásoló tényezók McCreadie és Tinker folyamatmodellje segítségével tekinthetók át (McCreadie \& Tinker 2005). A kutatók az Egyesült Királyság idős korú lakossága köréból kiválasztott mintán vizsgálták az ST-használatot, az adott termékkel való elégedettséget és ennek kritikus tényezóit. A folyamatábra szerint az ST elfogadottsága attól függ, hogy a ter- 
mék tulajdonságai mennyiben felelnek meg a kialakult igénynek, míg az igény kialakulását a felhasználó adottságai és a környezetével folytatott interakciói határozzák meg.

A segítố technológiák alkalmazásánál felmerülő általános problémák a következók voltak:

1. Megfelelố eszközt kapott-e a felhasználó?

2. Használja-e az adott eszközt, és ha igen, miként?

3. Milyen mértékben válik függóvé az általa alkalmazott eszköztól?

Az első szempont az ST-alkalmazásoknál az, hogy az igénylőnek milyen megoldásra van szüksége. A rehabilitációban és a segítô technológiák kiválasztásának folyamatában számos szakember vesz részt (Chilkó 2007): szakorvosok, ápolók, gyógytornászok, logopédusok, pszichológusok, gyógypedagógusok, foglalkoztatási specialisták, szociális dolgozók, rehabilitációs mérnökök, informatikusok, technikusok és orvosmérnökök. A különféle szakértók közös nyelvhasználata, illetve egységes klasszifikációs rendszer hiányában hibák csúszhatnak a döntési folyamatba. A megfelelő termék és szolgáltatás kiválasztásához vezető folyamat sikere érdekében gondosan össze kell hangolni valamennyi közremúködó munkáját és kommunikációját.

A segítố technológiák alkalmazásának következố szintjén az a kérdés, hogy a felhasználó miként használja az adott eszközt. A használatba vételt megfelelố oktatásnak, kielégító tréningnek kell megelốznie. Gyakran nem aknázzák ki a technológiában rejlő lehetôségeket, és csak bizonyos funkciókat vesznek igénybe. A felhasználónak biztonsággal és hatékonyan kell tudnia üzembe helyezni és alkalmazni az eszközt, esetenként apróbb módosításokat (például utánállítást, finomhangolást) végrehajtva rajta. A speciális felhasználó életkörülményei is behatárolják a termék sikerességét. A jó alkalmazáshoz be kell vonni a családot: a családtagokat is fel kell készíteni a technológia ismeretére, hogy tudják, miként kell és lehet annak alkalmazását támogatni. Kritikus tényezố továbbá a munkahely is, fontos az ottani dolgozók felkészítése az új technológia megjelenésére, a helyiség akadálymentesítése és a megfelelő személyi feltételek biztosítása az előadódó problémák megoldására.

A segítô technológiák alapcéljából ered a harmadik kritikus probléma. Az ST-alkalmazások során a speciális felhasználó - önállóságának növekedésével párhuzamosan - nagymértékben függốvé válik az alkalmazott eszköztól. Minél inkább önellátóvá válik az adott személy, aki az eszköz birtokában képes elvégezni számára addig megoldhatatlan feladatokat, annál jobban függeni fog az eszközétól. Ha az vagy valamely hozzá kapcsolódó szolgáltatás (pl. internet-hozzáférés) meghibásodik, gyakran csapdába esik. Az ST-rendszereknél sokkal magasabb szintúek a megbízhatósági elvárások, mint a hétköznapi informatikai alkalmazásoknál. A rendszer iránti felhasználói bizalom nehezen alakul ki, és könnyen elvész, s a fogyatékkal élók és az idős emberek gyakran inkább nem használják az ilyen eszközöket. A technológiának való kiszolgáltatottságot gyakran átélik a hétköznapi emberek is (amikor pl. lemerül a mobiltelefonjuk), de ezek a problémák számukra általában áthidalhatók. A speciális felhasználók életvitelében azonban az ilyen eszközökre vagy az ambiens rendszerekre cselekvéseik és munkafolyamataik egész sorozata épülhet, és a technológiai berendezés meghibásodása alapjában béníthatja meg életvitelüket. Ezt a függést oktatással, tréninggel, esetleg saját meghibásodásukat is érzékelő intelligens eszközökkel és a környezet felkészítésével szokták optimalizálni. Bizonyos esetekben tartalékrendszereket és eszközöket is alkalmaznak a kiszolgáltatottság okozta stressz csökkentésére. 


\section{Összefoglalás}

Tanulmányunkban megpróbáltunk áttekintést nyújtani a fogyatékkal élók és az idôsek számára kidolgozott segítô technológiákról. Az ST definiálása és osztályozása után példákat mutattunk be a környezeti intelligencia ilyen irányú alkalmazására és a napjainkban fejlesztett intelligens ST eszközökre, terjedelmi korlátok miatt elsősorban a magyarországi eredmények és az innovatív külföldi megoldások felvillantására törekedve.

Írásunkból kiderül, hogy a segítố technológiák fejlesztésében kiemelt szerephez jutnak a használhatósági szempontok. A rehabilitáció területén megfigyelhetố betegségközpontú felfogást felváltotta a kliensközpontú szemlélet, és az informatikai rendszerek fejlesztésénél is hasonló tendencia érvényesül: az alkalmazott technológiára koncentráló szemléletet egyre inkább a használati helyzetet a középpontba állító felfogás váltja fel. Az ST esetében a felhasználó és az eszköz speciális kapcsolatba kerül, mivel a fogyatékkal élő nemcsak használja az eszközt, hanem erôsen függ is attól, tehát a technológia megbízhatósága különösen fontos.

Mivel igen sok információs technológiai megoldás az emberi munkavégzés megkönnyítése vagy a kellemesebb életvitel támogatása céljából jött létre, a legtöbb informatikai innováció valamilyen szálon kötôdik a segítố technológiákhoz, vagy összekapcsolható ezekkel. Napjainkban az ST az informatika egyik legdinamikusabban fejlődő területének tekinthetô, amely megkérdôjelezhetetlen hasznossága miatt a jövốben jelentôs szemléletbeli változást okoz majd a társadalom és az informatika viszonyában is.

\section{Irodalom}

Abledata. http:// www.abledata.com/

ALADIN. http://www.ambient-lighting.eu/

Amemiya, T. 2007. Handheld Haptic Display with Braille I/O. In Stephanidis, C. (Ed.): Universal Access in Human-Computer Interaction: Ambient Interaction. Proceedings of the 4th International Conference on Universal Access in Human-Computer Interaction (Part II). Beijing, P. R. China, 22-27, 730-739.

Argus II. http://www.usc.edu/uscnews/stories/13442.html

Billi, M. - Burzagli, L. - Emiliani, P. L. - Gabbanini, F. - Graziani, P. 2006. A Classification, Based on ICF, for Modelling Human Computer Interaction. Computers Helping People with Special Needs, 407-414.

Chilkó S. 2007. A támogató technológiák alapjai. In Szabó Gy.: Tervezés speciális felhasználói körök számára. Oktatási segédlet. 18-36. www.ergonomiavilaga.hu.

Cowan, J. - Turner-Smith, A. 1998. The Role of Assistive Technology in Alternative Models of Care for Older People, With Respect To Old Age. Research Vol. 2, Appendix 4, HMSO.

Dasher. http://www.inference.phy.cam.ac.uk/dasher/

Egészségügyi Mérnöki Tudásközpont. http://emt.bme.hu/

Ettinger, R. C. - Bostrom, N. - Tandy, C. 2005. Man into Superman: The Startling Potential of Human Evolution - and How to Be Part of It. Ria University Press.

EVITA. http://evita.njszt.hu/tanulmany/hattertanumany-az-evita-nemzeti-program-megalapozasara

„EVITA Infokommunikáció az életvitel szolgálatában” szakkiállítás és vásár

http://www.ivsz.hu/engine.aspx?page=evita-magyar 
Forgács I. 2000. Az egészség ára. Magyar Tudomány.

Gelderblom, G. J. - Witte, L. P. 2002. The Assessment of Assistive Technology Outcomes, Effects and Costs. Technology and Disability, 91-94.

HCI International 2007 konferencia. http://www.hcii2007.org/

Hoppestad, B. S. 2006. Essential elements for assessment of persons with severe neurological impairments for computer access utilizing assistive technology devices: A Delphi study. Disability and Rehabilitation: Assistive Technology, 3-16.

ICF. http://www.who.int/classifications/icf/site/index.cfm

i-Limb. http://www.touchbionics.com/professionals.php?section=4

Intellidrug. http://www.intellidrug.org/

KeyStrokes 4.0. http://www.assistiveware.com/keystrokes.php

King's Fund consultation. 2001. Letöltés dátuma: 2008. február 11, forrás: FAST - Foundation For Assistive Technology: http://www.fastuk.org

Laufer, L. 2006. Jelentés a Pervasive Health 2006 konferenciáról. Konferencia Tudásbank: http://www.konferencia-tudasbank.hu/reports/view/22

Lorincz, A. - Takics, B. - Szabo, Z. - Poczos, B. - Biczo, M.- Hevizi, G. 2004. Hidden Markov model finds behavioral patterns of users working with a headmouse driven writing tool. Neural Networks, 2004. Proceedings. 2004 IEEE International Joint Conference on, vol.1, 669-674.

McCreadie, C. - Tinker, A. 2005. The acceptability of assistive technology to older people. Ageing छे Society, 25, 91-110.

Rheo Knee. http://www.ossur.com/pages/2734

Tremor adapter. http://domino.watson.ibm.com/comm/pr.nsf/pages/news.20050314_ mouseadapter.html

WHO (2004). WHO. Letöltés dátuma: 2008. február 11, forrás: http://whqlibdoc.who.int/wkc/2004/WHO_WKC_Tech.Ser._04.2.pdf 